\title{
ЗМІНИ АМПЛІТУДНО-ЧАСТОТНОГО СПЕКТРУ КОЛИВАНЬ КРОВОТОКУ ПІД ЧАС ОПЕРАТИВНИХ ВТРУЧАНЬ 3 ПРИВОДУ СПАЙКОВОЇ КИШКОВОЇ НЕПРОХІДНОСТІ
}

\author{
I.М. Дейкало ${ }^{1}$, В.В. Буката ${ }^{1}$, А.В. Чорномидз ${ }^{2}$ \\ ${ }^{1}$ Тернопільський національний медичний університет імені І.Я. Горбачевського МОЗ України, \\ кафедра загальної хірургії, м. Тернопіль, Україна, \\ ORCID ID: 0000-0002-0095-4862, \\ ORCID ID: 0000-0001-9638-1052, \\ e-mail:bukatavv@tdmu.edu.ua, \\ ${ }^{2}$ Тернопільський начіональний медичний університет імені І.Я. Горбачевського МОЗ Украӥни, \\ кафедра фармакології з клінічною фармакологією, м. Тернопіль, Україна, \\ ORCID ID: 0000-0001-5479-8298 \\ e-mail: chornomydz@tdmu.edu.ua
}

Резюме. Мета роботи: дослідити зміни амплітудно-частотного спектру коливань кровотоку протягом інтраопераційного періоду у пацієнтів із спайковою кишковою непрохідністю.

Матеріали та методи дослідження. Нами обстежено 57 хворих на гостру спайкову кишкову непрохідність. Серед них 31 хворий прооперований відкритим способом та 26 хворих, яким проведено малоінвазивні втручання. Усім хворим проведено лазерну допплерівську флоуметрію. Обстеження проводили у безперервному режимі протягом усього оперативного втручання. Аналіз амплітудно-частотного спектру коливань кровотоку проводили за допомогою вейвлет-аналізу.

Результати дослідження. Встановлено, що протягом оперативного втручання стан мікроциркуляції зазнає змін залежно від періоду оперативного втручання. В усіх хворих на початку операції відмічається зростання усіх амплітуд коливань кровотоку. В подальшому при лапаротомних оперативних втручаннях виявлені зміни, що вказують на зниження кровопостачання тканин, підвищення резистентності артеріол та порушення відтоку крові з капілярного русла. При лапароскопічних втручаннях виявлено ознаки зниження функціональної активності ендотелію, зростання тиску у капілярах, виникнення застою в капілярному руслі.

Висновки. В обстежених хворих інтраопераційно виявлено значні зміни на рівні системи мікроциркуляції, що можуть призвести до гіпоксії органів та систем, розвитку дисфункції паренхіматозних органів, зростання ризику розвитку тромбоемболічних ускладнень та ін. Отже, як відкриті, так і лапароскопічні оперативні втручання мають, відносно досліджуваних показників, свої переваги та недоліки, на які необхідно звертати увагу під час хірургічного лікування спайкової кишкової непрохідності.

Ключові слова: спайкова кишкова непрохідність, лазерна допплерівська флоуметрія, вейвлет-аналіз, мікроциркуляція, інтраопераційний період.

Вступ. Ключовим етапом у перебігу хірургічних захворювань $\epsilon$ інтраопераційний період, у якому закладаються основні патогенетичні механізми подальшого розвитку захворювання та післяопераційних ускладнень $[1,2,3]$. Одними 3 основних факторів розвитку ускладнення в післяопераційному періоді $\epsilon$ гіпотермія, зміни в обміні речовин та мікроциркуляторні порушення під час проведення оперативного втручання, які впливають на основні патогенетичні механізми подальшого перебігу захворювання $[2,4,5]$. Протягом оперативного втручання на стан мікроциркуляторного русла впливає велика кількість факторів. Найважливіші серед них - лікарські препарати, які використовують для премедикації, міорелаксації та наркозу [6], реакція організму на хірургічну травму [4], гіпотермія внаслідок втрати тепла через операційну рану [3], інтоксикація, спричинена основним захворюванням, порушення вуглеводного обміну, зміни у системі коагуляції тощо. Важливою є реакція організму на операційну травму, яку прирівнюють до синдрому системної запальної відповіді та в якій задіяні симпатична вегетативна нервова, ендокринна та імунна системи. [4, 7].

Порушення функціонування системи мікроциркуляції в інтраопераційному періоді можуть призвести до розвитку гіпоксії тканин $[1,6,8]$, підвищення згортання крові та утворення мікротромбів [5], порушення терморегуляції [3] та набряку тканин внутрішніх органів. Особливо небезпечним є зростання ризику тромбоутворення, на що вказує більшість дослідників [9]. Це стосується й лапароскопічних втручань, коли ризик розвитку тромбозу підсилюється застосуванням пневмоперитонеуму $[9,10,11]$.

Усі вказані порушення, які виникають через дисфункцію мікроциркуляторного русла, впливають на роботу внутрішніх органів, зокрема паренхіматозних, i тим самим провокують виникнення післяопераційних ускладнень та розвиток поліорганної недостатності [12].

Про необхідність контролю протягом опера- 
тивного втручання показників гемодинаміки та мікроциркуляції відомо давно. Так, 100 років тому Гарві Кушинг вперше запропонував контролювати артеріальний тиск та частоту серцевих скорочень у пацієнтів під час і після операцій [13]. Американське товариство анестезіологів у 1986 році дійшло висновку, що оксигенацію крові, вентиляцію легень, стан циркуляції крові та температуру тіла слід обов'язково контролювати під час хірургічних втручань [14]. Запропонований моніторинг, на їх погляд, допоможе лікарям виявляти і попереджувати ускладнення в інтраопераційному періоді та в найбільш ранні строки після операції [14].

Серед багатьох методів дослідження стану мікроциркуляції досить зручним, інформативним та неінвазивним $є$ лазерна допплерівська флоуметрія, яка дає можливість здійснювати моніторинг перфузії периферичних тканин упродовж усього оперативного втручання $[12,15,16]$. Методика дає змогу швидко та точно визначити стан мікроциркуляції як на конкретний момент часу, так i в динаміці захворювання $[16,17,18]$. Окрім того, цей метод дає можливість аналізувати впливи різних факторів на мікроциркуляцію, тобто встановити зміни основних механізмів регуляції периферичної гемодинаміки $[12,15,16]$.

Метою нашої роботи було дослідити зміни амплітудно-частотного спектру коливань кровотоку протягом інтраопераційного періоду у пацієнтів із спайковою кишковою непрохідністю при проведенні лазерної допплерівської флоуметрії.

Матеріали та методи обстеження. В основу нашої роботи покладені результати спостережень за 57 хворими на гостру спайкову кишкову непрохідність, які перебували на стаціонарному лікуванні в хірургічному відділенні КНП ТМКЛШД в період 3 2015 по 2018 роки.

Нами обстежено 31 хворого, прооперованого відкритим способом, та 26 хворих, яким проведено малоінвазивні втручання. Клініко-лабораторне та інструментальне обстеження хворих на гостру спайкову кишкову непрохідність та план лікувальних заходів проводили відповідно до критеріїв діагностики та оцінки тяжкості стану згідно з наказом MO3 України № 297 від 02.04.2010. «Клінічні протоколи надання медичної допомоги хворим з гострими запальними захворюваннями черевної порожнини».

Для аналізу стану мікроциркуляторного русла та механізмів його регуляції проведено лазерну допплерівську флоуметрію на одноканальному лазерному аналізаторі мікроциркуляції «ЛАКК-ІІ» (НПП "Лазма", РФ) при довжині лазерного променя 0,8 мкм. Обстеження проводили в завушній ділянці справа у безперервному режимі, починаючи від укладки хворого на операційний стіл і закінчуючи завершенням оперативного втручання. Весь термін дослідження умовно поділений на 3 періоди. Перший період складав близько 15-20 хвилин, починався від укладки хворого на операційний стіл до початку оперативного втручання (розрізу). Другий період складав перші 30 хвилин оперативного втручання. I третій період тривав, починаючи від 30 хвилини операції до закінчення оперативного втручання. Дані періоди вибрано із врахуванням фізіологічних особливостей наркозу та передопераційної підготовки. Так, у перший період повинен проявлятись вплив препаратів передопераційної підготовки та премедикації (спазмолітики, Мхоліноблокатори, наркотичні анальгетики, антигістамінні засоби, інфузійна терапія) та вплив на організм больового синдрому, психоемоційних переживань та ін. У другому періоді нами оцінювався вплив препаратів для наркозу на центральні та периферичну гемодинаміку (централізація кровообігу, пригнічення центральних ланок регуляції кровопостачання та терморегуляції). У третьому періоді вивчалися компенсаторні реакції мікроциркуляторного русла у відповідь на тривалий вплив препаратів для наркозу та зміни температурного гомеостазу [12].

Під час обстеження ми оцінювали як базові показники мікроциркуляції (стан перфузії тканин (M)), так і амплітудно-частотний спектр (АЧС) коливань кровотоку [15]. Як відомо, на теперішній час для аналізу АЧС коливань кровотоку застосовують три алгоритми обчислення: швидке перетворення Фур'є, набір математичних вузькосмугових фільтрів Butterworth i Вейвлет-перетворення [15]. Нами використано Вейвлет-перетворення $[15,16,19]$, яке найкращим чином виявляє періодичність коротких і тривалих процесів, представлених в одній реалізації. Весь діапазон частот прийнято розділяти на активні і пасивні фактори регуляції кровотоку. До пасивних відносяться механізми притоку крові в мікроциркуляторне русло (пульсова хвиля, серцеві коливання) та механізми відтоку крові (дихальні коливання). Активні механізми регуляції, що змінюють м'язовий судинний тонус: ендотеліальні, нейрогенні і міогенні $[15,16]$ (табл. 1).

Таблиця 1

Частотна характеристика ритмічних скорочень кровотоку у мікроциркуляторному руслі $[15,16]$ Діапазони частот коливань кровотоку

$0,0095-0,02$ Гц

$0,02-0,052$ Гц

$0,052-0,069$ Гц

$0,07-0,12$ Гц

$0,12-0,18$ Гц

$0,2-0,4$ Гц

$0,8-1,6 \Gamma ц$
Діагностичне значення частотних діапазонів ендотеліальна активність (секреція NO)

нейрогенна активність (вплив симпато-адреналової системи)

сенсорна пептидергічна іннервація міогенна активність (ендотелій незалежна регуляція) холінергічна (парасимпатична) активність дихальні ритми (венозний відтік крові) серцеві ритми (артеріальний притік крові) 
Статистичну обробку даних здійснювали шляхом застосування методів дослідження випадкових величин та описової статистики. Первинну обробку отриманих даних проводили методами описової статистики 3 поданням результатів для кількісних ознак у вигляді: кількості спостережень (n), середньої арифметичної (M), стандартно-квадратичного відхилення $(\sigma)$. Вірогідність відхилення двох рядів значень обчислювали з використанням t-тесту Стьюдента для незалежних величин. Для з'ясування впливу різних факторів на значення досліджуваних показників використовували однофакторний дисперсійний аналіз ANOVA, використовуючи комп'ютерні програми Statistica v 10.0 (StatSoft Inc.) та Microsoft ${ }^{\circledR}$ Excel 2007. Критичне значення рівня значущості (р) приймалося $<5 \%$.

Результати обстеження та їх обговорення. Нами встановлено, що у хворих, оперованих відкритим способом, у першому періоді оперативного втручання відмічається достовірне зростання амплітуди ендотеліальних коливань порівняно 3 показниками здорових осіб $(\mathrm{p}<0,05)$, в подальшому цей показник різко знижується $(\mathrm{p}<0,05)$ і до кінця операції не перевищує значення здорових осіб.

У перший період лапароскопічних оперативних втручань виявлено достовірне зростання амплітуди ендотеліальних коливань, як і в попередній групі (рис. 1). На відміну від значень при лапаротомних втручаннях, у цій групі хворих високі значення амплітуди ендотеліальних коливань у другому періоді залишаються високими і лише у третьому періоді знижуються до значень здорових осіб.

Зміни амплітуди нейрогенних коливань протягом оперативних втручань схожі на попередньо описані. Так, при лапаротомних операціях з приводу спайкової кишкової непрохідності виявлено на початку операції різке підвищення рівня цього показника у більш, як 2 рази, порівняно із групою здорових осіб $(\mathrm{p}<0,05)$. У другому періоді амплітуда нейрогенних коливань різко знижується, нижче за нормальні значення $(\mathrm{p}<0,05)$, і в третьому періоді дещо зростає i стає рівною показникам здорових осіб $(\mathrm{p}>0,05)$.

\section{Амплітуда ендотеліальних коливань}
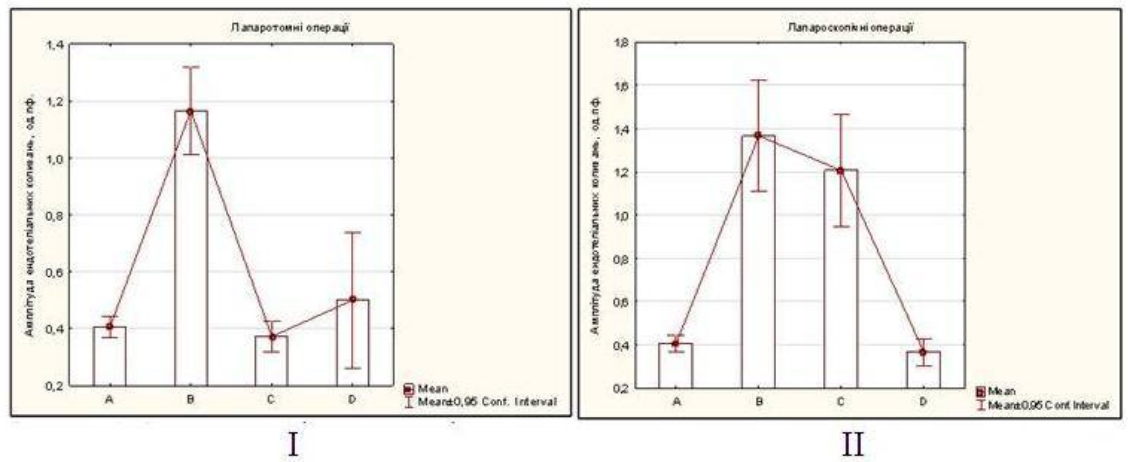

Амплітуда нейрогенних коливань

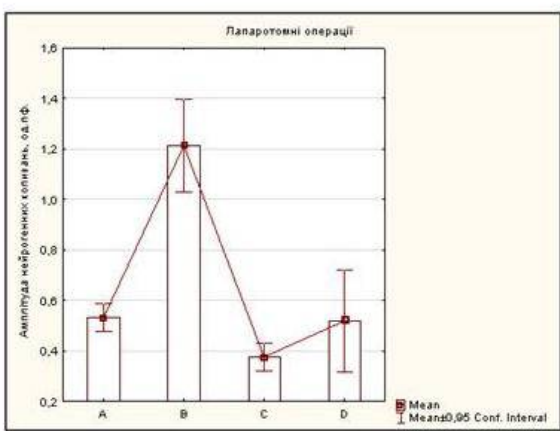

I

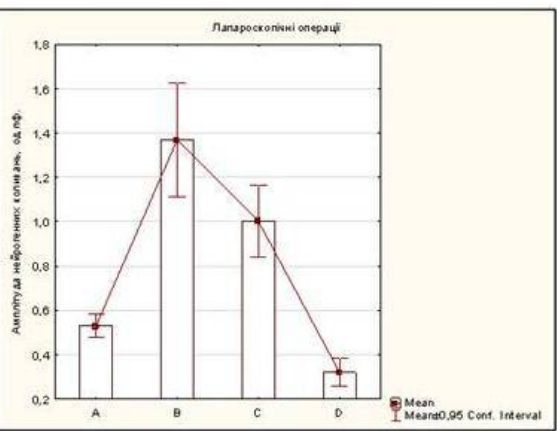

II

Рис. 1. Значення амплітуди ендотеліальних та нейрогенних коливань протягом лапаротомних (I) та лапароскопічних (II) оперативних втручань (А - показники здорових осіб; В - I період операції; C - II період операції; D - III період операції).

При проведенні лапароскопічних втручань виявлено аналогічне зростання амплітуди нейрогенних коливань на початку операції. У другому періоді операції рівень цього показника достовірно знижувався $(\mathrm{p}<0,05)$, але залишався приблизно в 2 рази вищим за значення здорових осіб $(\mathrm{p}<0,05)$. У третьому періоді операції виявлено різке зниження амплітуди нейрогенних коливань, нижче за значення у осіб без соматичної патології $(\mathrm{p}<0,05)$. Аналізуючи значення цього показника залежно від типу оперативного втручання, найбільш достовірна різниця стосується другого періоду операції, де при відкритому операти- 
вному втручанні амплітуда нейрогенних коливань на $30 \%$ нижча за норму, тоді як при проведені лапароскопічного адгезіолізису - на 98\% вища за значення здорових осіб.

Зміни амплітуди міогенних коливань при проведені лапаротомних оперативних втручань носять такий характер: на початку операції виявлено зростання цього показника в 2 рази порівняно із значеннями здорових осіб, в другому періоді - різке зниження амплітуди (на 28\% нижче за показники осіб без соматичних патологій) та утримання низьких значень амплітуди міогенних коливань до кінця оперативного втручання (рис. 2).

При проведенні лапароскопічного адгезіолізису встановлено на початку оперативного втручання зростання амплітуди міогенних коливань на 155\% порівняно із групою здорових осіб, аналогічно, як i при лапаротомних втручаннях. У подальшому, на відміну від попередньої групи, немає різкого зниження цього показника. Так, у другому періоді відмічається зниження амплітуди міогенних коливань на $35 \%$ і цей показник залишається вище норми приблизно в 2 рази. У третьому періоді оперативного втручання амплітуда міогенних коливань стає рівною 3 показниками здорових осіб (p>0,05).

Зміни амплітуди дихальних коливань протягом оперативного втручання дещо відрізняються від описаних вище показників. Так, на початку відкритих оперативних втручань виявлено зростання амплітуди дихальних коливань більш, як у 6 разів, порівняно із показниками здорових осіб $(\mathrm{p}<0,05)$.

У другому періоді операції амплітуда дихальних коливань знижується на 54\% та утримується на такому рівні до кінця оперативного втручання, залишаючись у 2,8 рази вищою від показників здорових осіб.

При лапароскопічних оперативних втрачаннях виявлено, після різкого зростання амплітуди дихальних коливань, аналогічного, як і в попередній групі, поступове зниження цього показника. Так, у другому періоді операції амплітуда знижується на $19 \%(\mathrm{p}>0,05)$, а в третьому - на 30\% (p<0,05). При цьому амплітуда дихальних коливань достовірно вища у другому і третьому періодах оперативних втручань порівняно із групою хворих, яким проведено відкриті операції з приводу спайкової кишкової непрохідності $(\mathrm{p}<0,05)$.

\section{Амплітуда міогенних коливань}
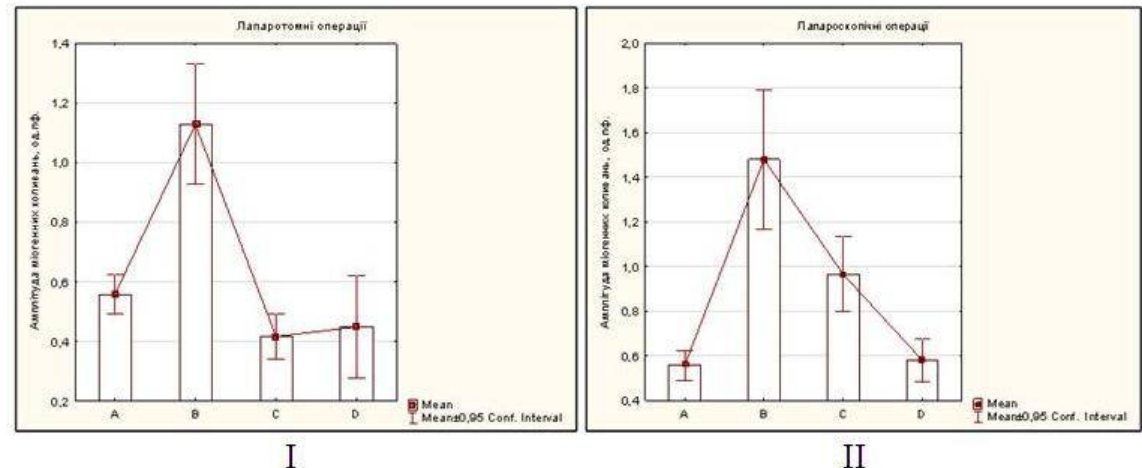

II

Амплітуда дихальних коливань
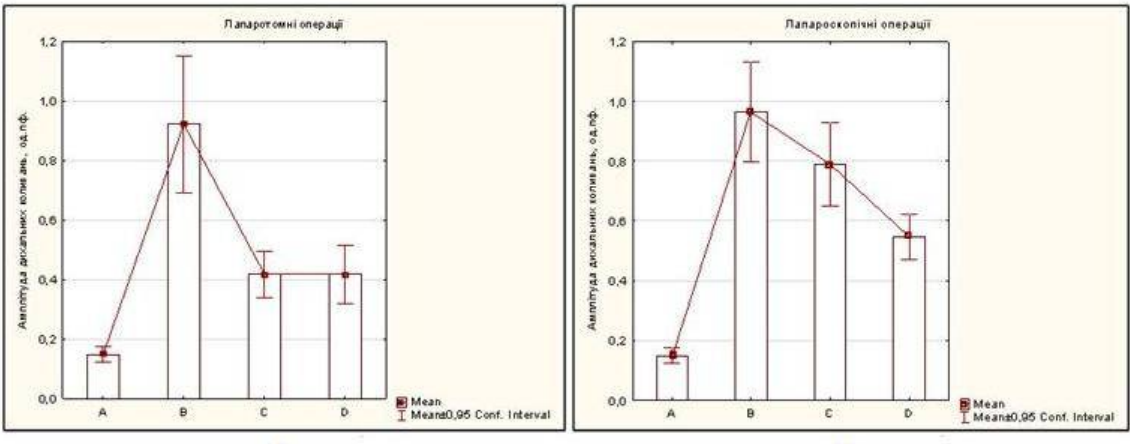

I

II

Рис. 2. Значення амплітуди міогенних і дихальних коливань протягом лапаротомних (I) та лапароскопічних (II) оперативних втручань (А - показники здорових осіб; В - I період операції; C - II період операції; D - III період операції).

Аналіз змін амплітуди серцевих коливань показав, що у хворих, оперованих відкритим способом, на початку операції цей показник зростав на 63\% порівняно з групою здорових осіб. У другому періоді операції виявлено зниження амплітуди дихальних коливань приблизно у 1,5 рази $(\mathrm{p}<0,05)$ і в подальшо- му ці значення утримувались до завершення оперативного втручання, будучи в 2 рази вищими за значення групи здорових осіб $(\mathrm{p}<0,05)$.

При проведенні лапароскопічного адгезіолізису на початку оперативного втручання амплітуда серцевих коливань була на $69 \%$ вища за значення 
здорових осіб $(\mathrm{p}<0,05)$. У подальшому виявлене поступове зниження цього показника. Так, у другому періоді він знижувався на 19\% (p>0,05), а в третьому - на 48\% ( $<0,05)$, залишаючись достовірно вищим від значень у здорових осіб $(\mathrm{p}<0,05)$.

Аналізуючи отримані показники амплітудночастотного аналізу, ми прийшли до висновку, що визначення максимальної амплітуди коливань $\epsilon$ не зовсім зручним для визначення змін у регуляції мікроциркуляторного русла між окремими групами обстежених або ж у динаміці. Також максимальні амплітуди коливань кровотоку напряму залежать під показника мікроциркуляції, що також ускладнює порівняння показників між групами обстежених. Для повноцінного аналізу вкладу у регуляцію кожного компоненту необхідним є визначення відсоткового значення кожного регуляторного фактору із використанням запропонованої нами формули:

$$
A 1 \%=\frac{A 1}{\sum A 1+A 2+A 3+A 4+A 5} \times 100 \%
$$

де А1\% - складова частка амплітуди досліджуваних коливань (А1); $\underset{\text { коливань. }}{\sum(\mathrm{A} 1+\mathrm{A} 2+\mathrm{A} 3+\mathrm{A} 4+\mathrm{A} 5)-\text { сума амплітуд усіх }}$

При цьому встановлено, що у здорових осіб основний вплив на регуляцію кровонаповнення мікроциркуляторного русла справляють симпатоадреналова система та власний тонус судинної стінки (амплітуди нейрогенних та міогенних коливань). Досить вагомий вклад у регуляцію кровотоку здійснює судинний ендотелій, частка впливу якого у механізмах керування судинним тонусом складає близько $25 \%$. Активність дихальних та серцевих компонентів регуляції кровотоку досить незначна (табл. 2).

При цьому у хворих, які оперовані лапаротомно, відсоток впливу ендотеліального фактору достовірно не відрізнявся від показників здорових осіб, хоча і в динаміці цей показник знижувався $(\mathrm{p}<0,05)$. Також встановлене достовірне зниження впливу на кровотік нейрогенного та міогенного компонентів 3 одночасним зростанням дихального і серцевого механізмів регуляції (зростання пасивних факторів регуляціі).

Таблиця 2

Відсотковий вклад основних механізмів у регуляцію кровотоку протягом оперативних втручань у хворих із спайковою кишковою непрохідністю

\begin{tabular}{|l|c|c|c|c|c|}
\hline $\begin{array}{l}\text { Група обстежених } \\
\text { I } \\
\text { період операції }\end{array}$ & АЕ\% & АН\% & АМ\% & АД\% & АС\% \\
\hline \multicolumn{7}{|c|}{ Лапаротомні операції (n-31) } \\
\hline I період операції & $25,96 \pm 1,30$ & $25,78 \pm 0,92^{*}$ & $22,89 \pm 0,76^{*}$ & $18,57 \pm 0,20^{*}$ & $6,81 \pm 0,31$ \\
\hline II період операції & $21,59 \pm 0,83 \square$ & $21,35 \pm 0,50^{*} \square$ & $23,45 \pm 0,63^{*}$ & $23,05 \pm 0,81^{*} \square$ & $10,56 \pm 0,51^{*} \square$ \\
\hline III період операції & $21,08 \pm 0,89$ & $24,17 \pm 0,53^{*} \square$ & $21,20 \pm 0,52^{*} \square$ & $21,68 \pm 0,84^{*}$ & $11,86 \pm 0,64^{*}$ \\
\hline \multicolumn{7}{|c|}{ Лапароскопічні перації (n-26) } \\
\hline I період операції & $24,45 \pm 0,41$ & $24,80 \pm 0,48^{*}$ & $25,83 \pm 0,51^{*}$ & $17,61 \pm 0,54^{*}$ & $7,30 \pm 0,35$ \\
\hline II період операції & $26,77 \pm 0,98^{*}$ & $24,08 \pm 0,77^{*}$ & $22,57 \pm 0,65^{*} \square$ & $18,92 \pm 0,79^{*}$ & $7,66 \pm 0,42$ \\
\hline III період операції & $18,22 \pm 0,80^{*} \square$ & $15,77 \pm 0,66^{*} \square$ & $28,15 \pm 0,71^{*} \square$ & $27,32 \pm 1,02^{*} \square$ & $10,53 \pm 0,58^{*} \square$ \\
\hline $\begin{array}{l}\text { 3дорові особи (n- } \\
\text { 34) }\end{array}$ & $23,54 \pm 0,46$ & $30,18 \pm 0,36$ & $31,17 \pm 0,51$ & $8,42 \pm 0,47$ & $6,70 \pm 0,34$ \\
\hline
\end{tabular}

Примітка: * - достовірність різниці між показниками і групою здорових осіб $\mathrm{p}<0,05$;

$\square-$ достовірність різниці між показниками та попередніми даними $\mathrm{p}<0,05$.

У хворих, які оперовані лапароскопічно, виявлено у другому періоді операції зростання впливу ендотеліального фактору регуляції із достовірним зниженням цього показника нижче значень здорових осіб ( $<<0,05)$. Як і при виконанні відкритих оперативних втручань, у цій групі хворих виявлено зниження відсотку впливу нейрогенних та міогенних механізмів із зростанням відсотку пасивних регуляторних механізмів. Але на відміну від попередніх показників в третьому періоді лапароскопічних оперативних втручань встановлено достовірно нижчі значення впливу ендотеліальних і нейрогенних механізмів та достовірно вищі показники міогенних і дихальних факторів, що свідчить про виражений застій крові у капілярному руслі.

Обговорення отриманих результатів. Таким чином, встановлено, що протягом оперативного втручання стан мікроциркуляторного русла зазнає змін залежно від періоду оперативного втручання. Незалежно від типу оперативного втручання в пер- ший період операції відмічається зростання усіх амплітуд коливань кровотоку. Це вказує на зростання кровопостачання тканин (амплітуди доливань напряму залежать від показника перфузії, який значно зростає), активацію усіх активних компонентів регуляції кровотоку (ендотеліального, нейрогенного та міогенного) як наслідок стресу, активації симпатоадреналової системи та реакції організму на введення препаратів для наркозу та премедикації [12]. В подальші періоди операції зміни у мікроциркуляторному руслі відрізняються залежно від типу оперативного втручання. Так, при лапаротомних оперативних втручаннях у другий період виявлено зниження активності усіх активних компонентів регуляції кровотоку, в деяких випадках вони нижчі, від показників у здорових осіб. Це пов'язано із впливом препаратів для наркозу на центральні ланки регуляції кровообігу та теплорегуляції. Внаслідок зниження впливу активних компонентів регуляції кровотоку виявлено зростання пасивних факторів (дихальних та серцевих компонен- 
тів). У третьому періоді оперативного втручання виявлено зниження впливу міогенного компоненту регуляції та незначне зростання нейрогенного фактору регуляції на тлі високих амплітуд дихальних та серцевих коливань. Це вказує на зниження кровопостачання периферичних тканин, підвищення резистентності артеріол та порушення відтоку крові з капілярного русла [15]. На тлі зниженої перфузії ці зміни вказують на розвиток гіпоксії периферичних тканин.

При лапароскопічних оперативних втручаннях у другому періоді операції виявлено повільне зниження амплітуди усіх компонентів регуляції кровотоку, але зміни у регуляції кровотоку були досить помітними. Так, у другому періоді оперативних втручань виявлено зростання впливу ендотеліальних механізмів із зниженням міогенних факторів. Найбільш вагомі зміни виявлено у третьому періоді лапароскопічних оперативних втручань. Зокрема, виявлено різке зниження впливу на мікроциркуляцію ендотеліальних і нейрогенних компонентів із різким зростанням впливу міогенних, дихальних і серцевих факторів.

Такі високі цифри відсотку впливу пасивних компонентів регуляції кровотоку та міогенних коливань свідчать про розвиток застою крові у капілярному руслі, стазу крові у капілярах, зростання гіпоксії периферичних тканин $[12,15]$. Незважаючи на більш повільні зміни амплітуд коливань у хворих при проведені лапароскопічних оперативних втручань, при завершенні операції у капілярах значно зростає тиск, виникає застій та перенаповнення капілярного русла, що може призвести до вираженої гіпоксії та тромбозів. Таким чином, як відкриті, так і лапароскопічні оперативні втручання мають, відносно досліджуваних показників, свої переваги та недоліки, на які необхідно звертати увагу під час хірургічного лікування спайкової кишкової непрохідності.

Висновки. Метод лазерної допплерівської флоуметрії може успішно використовуватись для моніторингу стану системи мікроциркуляції у хворих протягом оперативного втручання, для раннього виявлення порушень перфузії периферичних тканин. Отримані нами результати свідчать про значні зміни на рівні системи мікроциркуляції, зокрема такі, як застій у венозній системі, перенаповнення капілярного русла, що можуть призвести до гіпоксії органів та систем, розвитку дисфункції паренхіматозних органів, зростання ризику розвитку тромбоемболічних ускладнень та ін. Таким чином, вплив на виявлені зміни у мікроциркуляції дозволить значно покращити перебіг захворювання та уникнути важких ускладнень у хворих на спайкову кишкову непрохідність.

Перспективи подальших досліджень. Визначення стану мікроциркуляції у інтраопераційному періоді можна проводити не лише при операціях 3 приводу спайкової кишкової непрохідності, а й при інших захворюваннях. Отримані дані можна використати для прогнозування розвитку післяопераційних ускладнень та контролю ефективності профілактичних заходів. Окрім цього, метод лазерної допплерівської флоуметрії має і достатній науковий інтерес, враховуючи вирішальне значення стану мікроциркуляторного русла в патогенезі багатьох захворювань.

\section{References:}

1. Gragasin FS, Bourque SL and Davidge ST. Vascular aging and hemodynamic stability in the intraoperative period. Front. Physio. 2012; 3:74. doi: 10.3389/fphys.2012.00074

2. Marotto S, Bradbrook C, Zoff A. Anaesthetic complications and preparedness part 1: pre-and intraoperative complications. Companion Animal, 2018; 23(10):578584.

3. Datsyuk O, Kozlovsky I, Kozlovsky J, Dmitriev D, Datsyuk L. Diagnosis and prevention of perioperative hypothermia. Pain, Anaesthesia \& Intensive Care. 2016; 4:42-47. [In Ukrainian]

4. Schier R, Zimmer P. Riedel B. Perioperative inflammation and microcirculation in surgery: clinical strategies for improved surgical outcomes. In "Microcirculation Revisited - From Molecules to Clinical Practice", book edited by Lenasi $H$. Retrieved from https:/www.intechopen.com/books/ microcirculationrevisited-from-molecules-to-clinical-practice. 2016.

5. Haller G, Laroche T, Clergue F. Morbidity in anaesthesia: today and tomorrow. Best practice \& research Clinical anaesthesiology. 2011; 25(2):123-132.

6. Turek Z, Sykora R, Matejovic M, Cerny V. Anesthesia and the Microcirculation. Seminars in Cardiothoracic and Vascular Anesthesia. 2009; 13(4):249-258.

7. Dobson GP. Addressing the Global Burden of Trauma in Major Surgery. Frontiers in surgery. 2015; 2:43. doi:10.3389/fsurg.2015.00043

8. Stens J, de Wolf SP, van der Zwan RJ, Koning NJ, Dekker N A, Hering JP, Boer C. Microcirculatory perfusion during different perioperative hemodynamic strategies. Microcirculation. 2015; 22(4):267-275.

9. Nenashko IA. Intraoperating hypercoagulation syndrome as a factor of postoperative thrombosis in the venous system. Hospital Surgery. 2016; 4:59-62. [In Ukrainian]

10. Fira DB. Intraoperative sequence of actions when performing laparoscopic cholecystectomy in patients with concomitant varicose veins of the lower extremities. Hospital Surgery. 2016; 2:99-102 [In Ukrainian]

11. Kisljakov VV, Useinov EB, Grojzik KL. Ob opasnostyah i oslozhneniyah laparoskopicheskoy holetsistektomii [On the dangers and complications of laparoscopic cholecystectomy]. Kharkivska khirurhichna shkol. 2009; 4.1(36):207-209. [In Russian]

12. Deykalo I. M, Bukata VV, Chornomydz AV. Changes in microcirculatory bed while performing operative interventions for adhesive ileus. Klinicheskaia khirurgiia. 2018; 85(4):15-18.

13. Lawrence JP. Advances and new insights in monitoring. Thorac Surg Clin. 2005; 15:55-70.

14. Mcintosh N. Intensive care monitoring: past, present and future. Clin Med. 2002; 2:349-55.

15. Krupatkin AI, Sidorov VV. Lazernaya dopplerovskaya floumetriya mikrotsirkulyatsii krovi. Rukovodstvo dlya vrachey [Laser Doppler flowmetry of microcirculation of blood. Practical guide], Moscow. 2005. P.256. [In Russian]

16. Chornomydz I, Boyarchuk O, Chornomydz A. Perspektyvy vykorystannia lazernoi dopplerivskoi floumetrii v pediatrychnii praktytsi [Prospects for using laser Doppler phometry in pediatric practice]. Science 
Review. 2018; 2(9), 3:61-65 [in Ukrainian]

17. Barhatov IV. Laser doppler flowmetry for human blood microcirculation assessment. Kazan medical journal. 2014; 95(1):63-69. [In Russian]

18. Kulikov DA, Glazkov AA, Kovaleva YuA, Balashova NV, Kulikov AV. Prospects of Laser Doppler flowmetry application in assessment of skin microcirculation in diabetes. Saharnyiy diabet. 2017; 20, 4:279-285. [In Russian]

19. Bagno A, Martini R. Wavelet transform analysis of skin perfusion during thermal stimulation. Clin Hemorheol Microcirc. 2016; 25, 64(2):167-175.

\section{УДК 616.34007.272.-089-06:612.13 \\ ИЗМЕНЕНИЯ АМПЛИТУДНО-ЧАСТОТНОГО СПЕКТРА КОЛЕБАНИЙ КРОВОТОКА ВО ВРЕМЯ ОПЕРАТИВНЫХ ВМЕШАТЕЛЬСТВ ПО ПОВОДУ СПАЕЧНОЙ КИШЕЧНОЙ НЕПРОХОДИМОСТИ}

\section{И.Н. Дейкало ${ }^{1}$, В.В. Буката ${ }^{1}$, А.В. Чорномидз ${ }^{2}$}

${ }^{1}$ Тернопольский национальный медицинский университет имени И.Я.Горбачевского МОЗ Украины, кафедра общей хирургии, г. Тернополь, Украина, ORCID ID: 0000-0002-0095-4862,

ORCID ID: 0000-0001-9638-1052,

e-mail:bukatavv@tdmu.edu.ua

${ }^{2}$ Тернопольский национальный медицинский университет имени И.Я. Горбачевского МОЗ Украинь, кафедра фармакологии с клинической

фармакологией, г. Тернополь, Украина,

ORCID ID: 0000-0001-5479-8298,

e-mail:chornomydz@tdmu.edu.ua

Резюме. Цель работы: исследовать изменения амплитудно-частотного спектра колебаний кровотока в течение интраоперационного периода у пациентов со спаечной кишечной непроходимостью.

Материалы и методы исследования. Нами обследовано 57 больных острой спаечной кишечной непроходимости. Среди них 31 больной прооперирован открытым способом и 26 больных, которым проведены малоинвазивные вмешательства. Всем больным проведена лазерная допплеровская флоуметрия. Обследование проводили в непрерывном режиме в течение всей операции. Анализ амплитудночастотного спектра колебаний кровотока проводили с помощью вейвлет-анализа.

Результаты исследования. В течение оперативного вмешательства состояние микроциркуляции изменяется в зависимости от периода операции. У всех больных вначале операции отмечается рост всех амплитуд колебаний кровотока. В дальнейшем при лапаротомных оперативных вмешательствах обнаружены изменения, указывающие на снижение кровоснабжения тканей, повышение резистентности артериол и нарушение оттока крови из капиллярного русла. При лапароскопических оперативных вмешательствах обнаружены признаки снижения функциональной активности эндотелия, рост давления в ка- пиллярах и возникновение застоя в капиллярном русле.

Выводы. В обследованных больных интраоперационно обнаружены изменения на уровне системы микроциркуляции, которые могут привести к гипоксии тканей, развитию дисфункции паренхиматозных органов, увеличению риска развития тромбоэмболических осложнений и др. Таким образом, разные виды оперативных вмешательств имеют, относительно исследуемых показателей, свои преимущества и недостатки, на которые необходимо обращать внимание при лечении спаечной кишечной непроходимости.

Ключевые слова: спаечная кишечная непроходимость, лазерная допплеровская флоуметрия, вейвлет-анализ, микроциркуляция, интраоперационный период

\section{UDC 616.34007.272.-089-06:612.13 CHANGES OF AMPLITUDE-FREQUENCY SPECTRUM VIBRATIONS OF BLOOD FLOW DURING OPERATIONS IN PATIENTS WITH ADHESIVE INTESTINAL OBSTRUCTION}

\author{
I.M. Deykalo ${ }^{1}$, V.V. Bukata ${ }^{1}$, A.V. Chornomydz ${ }^{2}$ \\ ${ }^{I}$ I. Horbachevsky Ternopil National Medical University, \\ Department of General Surgery, Ternopil, Ukraine, \\ ORCID ID: 0000-0002-0095-4862 \\ ORCID ID: 0000-0001-9638-1052 \\ e-mail:bukatavv@tdmu.edu.ua \\ ${ }^{2}$ I. Horbachevsky Ternopil National Medical University, \\ Department of Pharmacology and Clinical \\ Pharmacology, Ternopil, Ukraine, \\ ORCID ID: 0000-0001-5479-8298 \\ e-mail:chornomydz@tdmu.edu.ua
}

Abstract. A key stage in the course of surgical diseases is the intraoperative period, which lays down the main pathogenic mechanisms for the further development of the disease and postoperative complications. One of the main factors in the development of complications in the postoperative period are microcirculatory disorders during surgery, which affect the main pathogenic mechanisms of the further course of the disease.

Among many methods of studying the microcirculation state, laser Doppler flowmetry, which makes it possible to monitor the perfusion of peripheral tissues throughout the surgical intervention, is quite convenient, informative and non-invasive.

The Aim of the study is to investigate the changes of the amplitude-frequency spectrum of fluctuations of blood flow during the intraoperative period in patients with adhesive intestinal obstruction by conducting laser Doppler flowmetry.

Materials and methods of research. We examined 57 patients with acute adhesive intestinal obstruction. Among them, 31 patients were operated open-ended and 26 patients, who had undergone less invasive intervention. For the analysis of the 
microcirculatory channel state and mechanisms for its regulation, laser Doppler flowmetry was performed. The examinations were carried out continuously during the entire surgical intervention. During the survey, we evaluated both the baseline microcirculation and the amplitude-frequency spectrum of blood flow fluctuations. The analysis of the amplitude-frequency spectrum of blood flow fluctuations was performed using waveletanalysis.

Research results. It was established that during the surgical intervention the microcirculatory channel state changes depending on the period of surgical intervention. Regardless of the type of surgical intervention in the first period of operation, growth of all amplitudes of fluctuations of blood flow is noted. This indicates an increase in blood supply to tissues, the activation of all active components of blood flow regulation (endothelial, neurogenic and myogenic) as a consequence of stress, activation of the sympatho-adrenal system and the reaction of the body to the administration of drugs for anesthesia and premedication. Subsequently, in laparotomic surgical interventions, changes were observed indicating a decrease in the blood supply of peripheral tissues, an increase in the resistance of arterioles, and a violation of the outflow of blood from the capillary bed. In laparoscopic surgical interventions in subsequent periods of the operation, significant changes in blood flow regulation, especially at the end of surgical interventions, were detected. In particular, a sharp decrease in the influence on the microcirculation of endothelial and neurogenic components with a sharp increase in the influence of myogenic, respiratory and cardiac factors was revealed. This indicates an increase in pressure in the capillaries, the occurrence of stagnation and overflow of the capillary bed, which can lead to severe hypoxia and thrombosis.

Conclusions. The obtained results indicate significant changes in the level of the microcirculation system, such as stagnation in the venous system, overflow of the capillary bed, which can lead to hypoxia of organs and systems, development of dysfunction of parenchymal organs, increased risk of thromboembolic complications, etc. Thus, both open and laparoscopic surgical interventions have, in relation to the studied parameters, their advantages and disadvantages that need to be addressed during surgical treatment of adhesive intestinal obstruction.

Keywords: adhesive intestinal obstruction, laser Doppler flowmetry, wavelet analysis, microcirculation, intraoperative period.

Стаття надійшла в редакцію 16.11.2019 р. 